\title{
ANALISIS COMPARATIVO DE TRES ORGANISMOS OPERADORES DE AGUA POTABLE EN EL NOROESTE DE MICHOACÁN
}

\section{COMPARATIVE ANALYSIS OF THREE DRINKING WATER OPERATING ORGANIZATIONS FOR IN NORTHWESTERN MICHOACÁN}

\author{
José L. Pimentel-Equihua ${ }^{1^{*}}$, Martha A. Velázquez-Machuca ${ }^{2}$, América A. Cervantes-Martínez ${ }^{3}$ \\ ${ }^{1}$ Colegio de Postgraduados-Campus Montecillo. Carr. México-Texcoco km 36.5, Montecillo, \\ Texcoco, Edo de Mex. 56230. (jequihua@colpos.mx). ${ }^{2}$ Instituto Politécnico Nacional-CIIDIR \\ Michoacán. Justo Sierra 28, Centro. Jiquilpan, Mich. 59510. (mvelazquezm@ipn.mx). \\ ${ }^{3}$ Instituto Politécnico Nacional-CIIDIR Michoacán. Justo Sierra 28, Centro. Jiquilpan, Mich. \\ 59510. (lasongmc@hotmail.com)
}

RESUMEN

El presente trabajo analiza y compara la gestión de tres organismos operadores de agua potable a poblaciones urbanas. El propósito es identificar cuál organismo operador realiza la mejor gestión y discutir cuáles de los indicadores utilizados podrían favorecer este resultado. Se estudian los casos de Sahuayo, Jiquilpan y Venustiano Carranza, Michoacán, a partir de indicadores de eficiencia y eficacia en la gestión: porcentaje de población abastecida, intermitencia o tandeos, horas de abasto al día, calidad del agua, tamaño del sistema, descentralización, tarifas, morosidad, sobreeempleo y autonomía financiera. Los resultados indican que el organismo operador de Venustiano Carranza tiene los indicadores más favorables: menor intermitencia y mayor número de horas/día del servicio, mejor calidad del agua (percepción), menor morosidad y mayor relación ingresos/egresos; una situación contraria se encontró para los sistemas de Sahuayo y Jiquilpan. El menor tamaño del organismo operador de agua municipal (OOAPAS) de Venustiano Carranza, mayor descentralización hacia las comunidades rurales (manejo autogestivo de los sistemas) y los menores costos por pozo podrían estar favoreciendo su autonomía financiera. A pesar de las diferencias en su eficiencia y eficacia, los tres organismos operadores han alcanzado una cobertura de agua potable mayor a la media nacional y cuentan con mecanismos compensatorios en el pago de tarifas para usuarios con escasos recursos. Un aspecto negativo de los tres OOAPAS es que no cuentan con mecanismos para garantizar la participación directa de los usuarios en la gestión.

Palabras clave: eficacia y eficiencia, gestión de agua potable, indicadores de gestión, municipios.

* Autor responsable * Author for correspondence.

Recibido: agosto, 2018. Aprobado: enero, 2019.

Publicado como ARTÍCULO en ASyD 18: 145-160. 2021.

\begin{abstract}
This study analyzes and compares the management of three drinking water operating organizations in urban populations. The purpose is to identify which operating agency performs the best management and to discuss which of the indicators used could favor this result. The cases of Sahuayo, Jiquilpan and Venustiano Carranza, Michoacán, were studied from indicators of management efficiency and effectiveness: percentage of population supplied, intermittence or rotation, supply hours per day, water quality, size of the system, decentralization, rates, default in payment, overemployment, and financial autonomy. The results indicate that the operating agency in Venustiano Carranza has the most favorable indicators: lower intermittence and higher number of hours/day of service, better water quality (perception), lower default in payment and higher income/expenditure rate; the contrary situation was found for the systems in Sahuayo and Jiquilpan. The smaller size of the municipal water operating organization (organismo operador de agua municipal, OOAPAS) in Venustiano Carranza, greater decentralization toward rural communities (self-management of the systems), and the lower costs per well could be favoring their financial autonomy. Despite the differences in their efficiency and effectiveness, the three operating organizations have reached greater drinking water coverage than the national mean and they have compensatory mechanisms in fee payment for users with scarce resources. A negative aspect of the three OOAPAS is that they do not have mechanisms to guarantee the direct participation of users in management.
\end{abstract}

Key words: effectiveness and efficiency, drinking water management, management indicators, municipalities. 


\section{INTRODUCCIÓN}

$\mathrm{E}$ 1 presente trabajo se plantea en el marco de la discusión en la agenda social latinoamericana sobre los factores que condicionan las capacidades de gestión sostenible de los organismos operadores municipales para el abasto y administración del agua potable a las poblaciones urbanas (Jouravlev, 2003; Barkin, 2011). En nuestro país la autoridad máxima del agua es el Estado, y tiene la responsabilidad de abastecer de servicios de agua a la población; esta responsabilidad se delega constitucionalmente en el municipio (Art. 115 de la Constitución) quien tiene la facultad de crear un organismo operador encargado del abasto, o en su caso concesionar el servicio a empresas mixtas o privadas.

En el ámbito académico existe el debate sobre las formas más eficaces (abasto continuo del servicio) y eficientes (control de pérdidas y consumos dispendiosos) (Ferro, 2017) de la gestión del agua, tanto para riego como para abasto de agua potable a comunidades rurales y ciudades, y acerca de quién es mejor gestor: el Estado, la iniciativa privada o los usuarios organizados (Ostrom, 1990; Palerm et al., 2000). En relación con los usuarios, en México la reestructuración de las leyes relacionadas con el manejo del servicio de agua potable, abrió las posibilidades de su participación al permitir que se constituyeran como personas morales (Galindo y Palerm, 2012), impulsando una mayor autogestión. En este sentido, puede decirse que se avanza en el establecimiento de un contexto jurídico favorable a las organizaciones de usuarios, aspecto que se considera fundamental en la búsqueda de alternativas que respondan adecuadamente a las necesidades sociales, y a la propuesta de una gestión social del agua basada en criterios como solidaridad, derecho humano al agua y participación de los usuarios en los procesos decisorios, lo que posibilita una mayor legitimidad social y la consideración de que el agua es un bien común (Barkin, 2006), un derecho social universal (Castro, 2007).

Por otro lado, diversos autores han documentado la eficacia y eficiencia de las organizaciones de usuarios en la gestión de sus sistemas de agua potable (Galindo y Palerm, 2012; Pimentel et al., 2012; Cervantes et al., 2017), mientras que otros han señalado un desempeño contrario en el funcionamiento de los organismos operadores de agua municipales

\section{INTRODUCTION}

T This study is established within the discussion framework of the Latin American social agenda about factors that condition the sustainable management capacities of municipal operating organizations for the supply and administration of drinking water to urban populations (Jouravlev, 2003; Barkin, 2011). In Mexico the maximum authority for water is the State, and it has the responsibility of supplying water services to the population; this responsibility is constitutionally delegated to the municipality (Art. 115 of the Constitution) which has the faculty of creating an operating agency in charge of supply, or if applicable to grant the concession of the service to mixed or private companies.

In the academic scope, there is the debate about the most effective (continuous supply of the service) and efficient (control of losses and wasteful consumption) forms (Ferro, 2017) of water management, both for irrigation and for drinking water supply to rural communities and cities, and about who is the best manager: the State, the private sector, or organized users (Ostrom, 1990; Palerm et al., 2000). In relation to users, in Mexico the restructuring of laws related to management of the drinking water service opened possibilities for their participation by allowing them to be constituted as legal entities (Galindo and Palerm, 2012), driving greater self-management. In this sense, it can be said that there are advances in the establishment of a favorable legal context for users' organizations, aspect that is considered essential in the search for alternatives that respond adequately to social needs, and in the proposal of social management of water based on criteria such as solidarity, human right to water, and users' participation in decision processes, which enables a greater social legitimacy and the consideration that water is a common good (Barkin, 2006), and a universal social right (Castro, 2007).

On the other hand, various authors have documented the effectiveness and efficiency of users' organizations in the management of their drinking water systems (Galindo and Palerm, 2012; Pimentel et al., 2012; Cervantes et al., 2017), while others have pointed out a contrary performance in the functioning of municipal water operating 
(OOAPAS) (Contreras, 2006; Martín et al., 2011). Esta variación resulta de la diversidad de problemas que enfrentan los OOAPAS en el país (Salazar y Lutz, 2015) y que está estrechamente relacionada con las características de cada sistema. La literatura consultada menciona diversos indicadores que se han usado para analizar esta gestión sostenible: autonomía financiera, frecuencia de abasto, número de tomas domiciliarias (Congreso de Michoacán de Ocampo. 2004; CONAGUA, 2014), calidad del agua, infraestructura suficiente y en buen estado, eficiencia hidráulica, participación pública, transparencia, tratamiento de aguas residuales, planeación (Cunha et al., 2015; Yonca et al., 2014; Halkijevic et al., 2017; Dong et al., 2018), eficiencia comercial, relación ingresos/costos, tarifas, costos de producción, sobreempleo (Salazar y Lutz, 2015; Ferro, 2017), entre otros.

En este trabajo se describe, analiza y compara el funcionamiento de tres organismos operadores de agua potable (Sahuayo, Jiquilpan y Venustiano Carranza) en la Ciénega de Chapala, Michoacán, con base en los indicadores: porcentaje de población abastecida, tamaño del sistema, intermitencia, horas de abasto/día, calidad del agua, descentralización, sobreempleo, tarifas, morosidad y autonomía financiera para identificar cuál organismo operador realiza la mejor gestión y discutir cuáles de los indicadores utilizados podrían favorecer este resultado. Las tres ciudades son relativamente cercanas entre sí, dos de ellas con poblaciones menores a 50,000 habitantes.

\section{METODOLOGÍA}

Los indicadores de gestión se seleccionaron de la bibliografía nacional e internacional considerando que brindaran información sobre el cumplimiento las metas 6.1 y 6.4 del Objetivo 6 de Los Objetivos del Desarrollo Sostenible ODS: acceso universal y equitativo al agua potable a precio asequible para todos, uso eficiente de los recursos hídricos, sostenibilidad del abastecimiento, participación de las comunidades locales en la gestión del agua, y lo enunciado en el Derecho Humano al agua (agua en cantidad suficiente, saludable, aceptable y asequible). En este sentido, los estudios de casos que comparten ciertas características (ubicación geográfica, características socio-económicas) permiten analizar la eficacia/eficiencia de esos OOAPAS utilizando un número reducido de indicadores, organizations (OOAPAS) (Contreras, 2006; Martín et al., 2011). This variation results from the diversity of problems that OOAPAS face in the country (Salazar and Lutz, 2015) and which is closely related to the characteristics of each system. The literature consulted mentions various indicators that have been used to analyze this sustainable management: financial autonomy, frequency of supply, number of household taps (Congreso de Michoacán de Ocampo. 2004; CONAGUA, 2014), water quality, sufficient infrastructure in good conditions, hydraulic efficiency, public participation, transparency, residual water treatment, planning (Cunha et al., 2015; Yonca et al., 2014; Halkijevic et al., 2017; Dong et al., 2018), commercial efficiency, income/cost rate, fees, production costs, overemployment (Salazar and Lutz, 2015; Ferro, 2017), among others.

In this study, the functioning of three drinking water operating organisms (Sahuayo, Jiquilpan and Venustiano Carranza) in Ciénega de Chapala, Michoacán, is described, analyzed and compared based on the following indicators: percentage of population supplied, size of the system, intermittence, hours of supply/day, water quality, decentralization, overemployment, fees, default in payment, and financial autonomy to identify which operating agency performs the best management and to discuss which of the indicators used could favor this result. The three cities are relatively close to one another, two of them with populations smaller than 50,000 inhabitants.

\section{METHODOLOGY}

The management indicators are selected from national and international bibliography taking into consideration that they will provide information about the fulfillment of goals 6.1 and 6.4 from Objective 6 of the Sustainable Development Goals (SDG): universal and equitable access to drinking water at an affordable price for all, efficient use of water resources, sustainability of supply, participation of local communities in water management; and what is stated in the Human Right to water (sufficient, healthy, acceptable and affordable water). In this sense, the case studies that share certain characteristics (geographic location, socioeconomic characteristics) allow analyzing the effectiveness/ efficiency of those OOAPAS by using a small 
siempre y cuando éstos se asocien con la obtención de información adecuada para identificar la problemática específica del sistema. La capacidad de gestión sostenible de los OOAPAS se analizó a través de la eficacia (abasto continuo de agua) y eficiencia (control de pérdidas y consumos dispendiosos) (Ferro, 2017) y los indicadores: porcentaje de población abastecida, intermitencia o tandeos (días de abasto a la semana), horas de abasto al día, calidad del agua (reportes técnicos y percepción de la población), tamaño del sistema (número de tomas domiciliarias), descentralización (hacia las comunidades rurales: \% de población rural abastecida por el OOAPAS y No. de comités comunitarios autogestivos), tarifas, morosidad, sobreeempleo (No. de empleados/1000 tomas) y autonomía financiera (ingresos/costos). La recopilación de información se realizó mediante entrevistas semiestructuradas a autoridades y funcionarios del agua y usuarios, recorridos de campo, consultas bibliográficas y hemerográficas y revisión de documentos oficiales. Las entrevistas a usuarios se aplicaron en 36 colonias de Sahuayo (51 viviendas), 16 de Jiquilpan (36 viviendas) y 7 de Venustiano Carranza (11 viviendas). A partir de la información obtenida, se hizo una descripción del funcionamiento, manejo y estructura administrativa de los organismos operadores y se analizó el comportamiento de los indicadores seleccionados para comparar el desempeño de los OOAPAS estudiados e identificar sus capacidades de gestión sostenible.

\section{RESULTADOS Y DISCUSIÓN}

\section{La zona de estudio}

Los municipios de Sahuayo, Jiquilpan y Venustiano Carranza se ubican en el noroeste del estado de Michoacán, dentro de la cuenca Lerma-Chapala. El clima es templado con lluvias en verano y precipitación anual de 700-800 mm (INAFED, 2014). La temperatura oscila entre 10 y $26^{\circ} \mathrm{C}$. La población total en los tres municipios es de 130 497; de éstos, $77 \%$ se concentra en las zonas urbanas (cabeceras municipales) y $23 \%$ en comunidades rurales (Cuadro 1). Las cabeceras municipales tienen el mismo nombre que el municipio. La ciudad de Sahuayo tiene $88.4 \%$ de la población del municipio, Jiquilpan $70.8 \%$ y Venustiano Carranza 51.1\% (INEGI, 2010). A nivel municipal, la cobertura del servicio number of indicators, as long as these are associated with obtaining adequate information to identify the specific problems of the system. The capacity for sustainable management of the OOAPAS was analyzed through effectiveness (continuous water supply) and efficiency (control of losses and wasteful consumption) (Ferro, 2017) and the indicators: percentage of population supplied, intermittence or batches (supply days per week), hours of supply per day, water quality (technical reports and population perception), size of the system (number of household taps), decentralization (toward rural communities: \% of rural population supplied by the OOAPAS and number of self-managing community committees), fees, default in payment, overemployment (number of employees/1000 taps), and financial autonomy (income/costs). Gathering information was carried out through semi-structured interviews with authorities and water officials and users, field visits, bibliographic and newspaper consultations, and reviewing official documents. The interviews with users were applied in 36 neighborhoods from Sahuayo (51 households), 16 from Jiquilpan (36 households) and 7 from Venustiano Carranza (11 households). Based on the information obtained, a description of the functioning, management and administrative structure of the operating agencies was made, and the behavior of the indicators selected was analyzed in order to compare the performance of the studied OOAPAS and to identify their capacities for sustainable management.

\section{RESULTS AND DISCUSSION}

\section{Study Zone}

The municipalities of Sahuayo, Jiquilpan and Venustiano Carranza are located in the northwestern part of the state of Michoacán, within the LermaChapala basin. The climate is temperate with summer rains and annual precipitation of 700$800 \mathrm{~mm}$ (INAFED, 2014). Temperature ranges between 10 and $26{ }^{\circ} \mathrm{C}$. The total population in the three municipalities is $130497 ; 77 \%$ of these are concentrated in the urban zones (municipal townships) and $23 \%$ in rural communities (Table 1). The municipal townships have the same name as the municipality. The city of Sahuayo has $88.4 \%$ of the municipal population, Jiquilpan $70.8 \%$ and 
Cuadro 1. Municipios bajo estudio y número de habitantes.

Table 1. Municipalities under study and number of inhabitants.

\begin{tabular}{lccc}
\hline \multicolumn{1}{c}{ Municipio } & $\begin{array}{c}\text { Total de } \\
\text { habitantes }\end{array}$ & $\begin{array}{c}\text { No. de habitantes en } \\
\text { la cabecera municipal }\end{array}$ & $\begin{array}{c}\text { No. de habitantes en } \\
\text { comunidades rurales }\end{array}$ \\
\hline Sahuayo & 72841 & 64431 & 8410 \\
Jiquilpan & 34199 & 24233 & 9966 \\
Venustiano Carranza & 23457 & 11987 & 11470 \\
\hline Total & 130497 & 100651 & 29846 \\
\hline
\end{tabular}

Fuente: INEGI, 2010. Source: INEGI, 2010.

(viviendas con agua entubada) en 2015 fue de 99.1, 97.2 y $98.3 \%$ en Sahuayo, Jiquilpan y Venustiano Carranza, respectivamente (INEGI, 2015).

\section{Estructura y funcionamiento de los organismos operadores (OOAPAS)}

Los OOAPAS de los tres municipios cuentan con personal de confianza y de base. El primer grupo permanece en el puesto regularmente durante el periodo del Ayuntamiento, mientras que el personal de base es más estable debido a la experiencia en el manejo operativo del sistema.

En el OOAPAS de Sahuayo el personal de confianza son el Director y Director Administrativo. En este municipio, la administración del agua potable ha pasado por diversas etapas, desde la gestión por una empresa privada a la municipalización del servicio. Actualmente, el servicio lo administra el Departamento de Agua Potable, Alcantarillado y Saneamiento, organismo dependiente financiera y operacionalmente del ayuntamiento. A partir de 1999 se iniciaron las gestiones en el cabildo para dotar de autonomía al OOAPAS, situación que no se ha podido concretar a la fecha, aunque legalmente estos organismos son descentralizados del municipio (Sandoval, 2011). En la práctica, la autoridad en materia de agua es el Ayuntamiento, específicamente el Presidente Municipal; éste último decide sobre aspectos estratégicos de la gestión del agua: elección de directivos y personal de confianza, aplicación de recursos financieros, condonación de adeudos a usuarios. Para las tareas relacionadas con la ampliación de la red, el organismo depende del Departamento de Obras Públicas del ayuntamiento.

El área de Operaciones del OOAPAS concentra las tareas relacionadas con la instalación de tomas de agua, corrección de fugas y distribución del agua; también asigna al personal de auxilio para efectuar
Venustiano Carranza 51.1\% (INEGI, 2010). At the municipal level, service coverage (households with piped water) in 2015 was 99.1, 97.2 and $98.3 \%$ in Sahuayo, Jiquilpan and Venustiano Carranza, respectively (INEGI, 2015).

\section{Structure and Functioning of Operating Organizations (OOAPAS)}

The OOAPAS of the three municipalities have trust and base personnel. The first group regularly stays in the position during the period of the Local Government, while the base staff is more stable due to experience in the operative management of the system.

In the Sahuayo OOAPAS, the trust personnel are the Director and Administrative Director. In this municipality, the management of drinking water has undergone various stages, from management by a private company to the municipality taking over the service. Presently, the service is managed by the Department of Drinking Water, Sewage and Sanitation, agency that is financially and operatively dependent on the Local Government. Since 1999 the negotiations in the town council began to give autonomy to the OOAPAS, situation that has not been completed yet, although legally these organizations are decentralized from the municipality (Sandoval, 2011). In practice, the authority in matters of water is the Local Government, specifically the Municipal President, who decides about strategic aspects of water management: selection of directors and trust personnel, application of financial resources, condonation of users' debts. For the tasks related to the expansion of the network, the agency depends on the Department of Public Works of the local government.

The Operations area of the OOAPAS concentrates the tasks related with the installation of water taps, correction of leaks, and water distribution; it also 
labores de limpieza u otras actividades dentro de los sistemas. Las cuadrillas operativas se organizan en grupos de 3 a 4 personas. La complejidad técnica de la red hidráulica exige cierta habilidad para su manejo y eso posibilita la permanencia de los operarios más experimentados en los puestos clave. El trabajo de monitoreo de las fugas del sistema lo realizan los "auxiliares de fontaneros y peones eventuales", contratados temporalmente.

En el OOAPAS Jiquilpan el personal de confianza son el Director general, Administrador y Director de Operaciones. El primero concentra la toma de decisiones respecto a la gestión y operación del sistema; el Administrador se encarga de aspectos de contabilidad, cobranza y atención a clientes, además de apoyar directamente a la Dirección general. Cuentan también con un encargado de cultura de agua. El Director de Operaciones tiene a su cargo las tareas operativas del sistema; éstas se llevan a cabo por personal de base organizado en cuadrillas (grupos de 3 a 4 personas vigiladas por un supervisor) denominadas de agua, bombeo, drenaje y almacén. Los trabajadores que ocupan puestos de base se organizan en un sindicato.

El OOAPAS de Venustiano Carranza cuenta con un Director que es designado por el Presidente Municipal. Para la operación y administración del organismo, el Director del OOAPAS se apoya en dos divisiones: 1) cobranza, que a su vez cuenta con un auxiliar, un contador y un cajero; 2) encargado de operación, del cual dependen dos fontaneros.

\section{Indicadores de gestión}

Tamańo de los sistemas. Los sistemas de agua potable están constituidos por las fuentes de agua y su red de distribución hasta las tomas de las viviendas. El tamaño de los sistemas (número total de tomas domiciliarias registradas) es un indicador de la complejidad de su manejo por parte de las autoridades puesto que un mayor tamaño aumenta los costos en vigilancia, monitoreo, mantenimiento, personal administrativo y auxiliar. Las fuentes de agua potable que manejan los OOAPAS son principalmente pozos profundos, aunque existen algunas norias y pequeños manantiales de menor importancia. Por tamaño, los OOAPAS siguen el orden: Venustiano Carranza $<$ Jiquilpan $<$ Sahuayo (Cuadro 2). La relación entre el número de tomas/número de pozos es cercana a 1500 en los tres casos. assigns the assistance personnel to carry out cleaning tasks or other activities within the systems. The operating crews are organized into groups of 3 to 4 people. The technical complexity of the hydraulic network demands certain skill for its management and this enables the permanence of the most experienced operators in key roles. The task of monitoring leaks in the system is performed by "plumber assistants and occasional day workers", who are hired temporarily.

In the Jiquilpan OOAPAS the trust personnel are the general Director, the Manager and the Operations Director. The first focuses on decision making regarding the system's management and operation; the Manager is in charge of aspects of accounting, collecting and customer service, in addition to directly supporting the general Director. There is also a person in charge of water culture. The Operations Director is in charge of the operative tasks of the system; these are carried out by base personnel organized into crews (groups of 3 to 4 people overseen by a supervisor) assigned to water, pumping, drainage, and storage. The workers who occupy base positions are organized into a union.

The Venustiano Carranza OOAPAS has a Director who is designated by the Municipal President. For the operation and administration of the organization, the OOAPAS Director is supported by two divisions: 1) collection, which at the same time has an assistant, an accountant and a cashier; 2) person in charge of operations, on whom two plumbers depend.

\section{Management Indicators}

Size of the systems. The drinking water systems are constituted by the water sources and their distribution networks toward household taps. The size of the systems (total number of registered household taps) is an indicator of the complexity of their management by the authorities, since a greater size increases the oversight, monitoring, maintenance, and administrative and auxiliary costs. The drinking water sources that OOAPAS manage are mainly deep wells, although there are some waterwheels and small springs of lesser importance. By size, the OOAPAS follow the next order: Venustiano Carranza< Jiquilpan $<$ Sahuayo (Table 2). The rate of number of taps/number of wells is close to 1500 in the three cases.

Intermittence and hours/day of service. Water distribution in Sahuayo and Jiquilpan is made by 
Cuadro 2. Fuentes de agua, número de tomas domiciliarias, intermitencia (tandeo) y horas/día del abasto de agua potable en Sahuayo, Jiquilpan y Venustiano Carranza, Michoacán.

Table 2. Water sources, number of household taps, intermittence (batches) and hours/day of drinking water supply in Sahuayo, Jiquilpan and Venustiano Carranza, Michoacán.

\begin{tabular}{lcclc}
\hline \multicolumn{1}{c}{ Ciudad } & $\begin{array}{c}\text { Fuentes de agua } \\
\text { (pozos) }\end{array}$ & $\begin{array}{c}\text { Número de } \\
\text { tomas }\end{array}$ & \multicolumn{1}{c}{$\begin{array}{c}\text { Intermitencia (tandeos) } \\
\text { del abasto }\end{array}$} & horas/día \\
\hline Sahuayo & 15 & 22000 & $\begin{array}{l}\text { Por secciones. 2 veces por semana a cada } \\
\text { sección (algunas secciones diario). } \\
\text { Por secciones. Cada tercer día a cada sección } \\
\text { (algunas secciones diario) }\end{array}$ & 7.5 \\
Jiquilpan & 8 & 13000 & Simultáneo. Todos los días & 8 \\
Venustiano Carranza & 3 & 4500 & &
\end{tabular}

Fuente: entrevistas a autoridades del agua. \& Source: Interviews with water authorities.

Intermitencia y horas/día del servicio. En Sahuayo y Jiquilpan la distribución del agua se lleva a cabo por secciones, intermitencia (tandeos) y horas variables de servicio (Cuadro 2). En el primer caso, $60 \%$ de la población cuenta con servicio diario y en el segundo (Jiquilpan) 16.6\%; el resto de la población recibe un servicio intermitente y en el caso de Venustiano Carranza 100\% de la población cuenta con el servicio diario. El abasto diario es un indicador de mejor desempeño puesto que garantiza en mayor medida que la población cuente con la cantidad suficiente de agua (50-100 litros/día/hab) (ONU, 2019). En este caso, el OOAPAS de Venustiano Carranza es el que tiene el indicador más alto (8 horas de abasto diario para todas las tomas), seguido de Sahuayo y Jiquilpan.

Calidad del agua. La calidad del agua potable es percibida como buena por un mayor porcentaje de usuarios en Venustiano Carranza que en Sahuayo o Jiquilpan (Cuadro 3). La percepción de los usuarios sobre este indicador reviste importancia dado que las características del agua que se considera potable deben incluir el que sea agradable en olor y sabor (SSA, sections, intermittence (batches) and variable hours of service (Table 2). In the first case, $60 \%$ of the population has daily service and in the second (Jiquilpan), 16.6\%; the rest of the population receives intermittent service and in the case of Venustiano Carranza, 100\% of the population has daily service. The daily supply is an indicator of better performance since it guarantees, to a greater extent, that the population receives the sufficient amount of water (50-100 liters/day/inhab) (ONU, 2019). In this case, the Venustiano Carranza OOAPAS is the one that has the highest indicator (8 hours of daily supply for all the taps), followed by Sahuayo and Jiquilpan.

Water quality. The quality of drinking water is perceived as good by a larger percentage of users in Venustiano Carranza than in Sahuayo or Jiquilpan (Table 3). The perception of users about this indicator is important given that the characteristics of the water that is considered drinkable should include that it should be pleasant in odor and flavor (SSA, 2000), and these aspects are the ones that are users basically observe in the flows that reach the households.

Cuadro 3. Percepción de los usuarios sobre el abasto y calidad del agua potable en las ciudades de Sahuayo, Jiquilpan y Venustiano Carranza.

Table 3. Perception of users about the supply and quality of drinking water in the cities of Sahuayo, Jiquilpan and Venustiano Carranza.

\begin{tabular}{lccc}
\hline \multirow{2}{*}{ Ciudad } & $\begin{array}{c}\text { Número de } \\
\text { entrevistas }\end{array}$ & $\begin{array}{c}\text { Calidad del agua } \\
(\%)\end{array}$ & $\begin{array}{c}\text { Mala o Regular } \\
(\%)\end{array}$ \\
\cline { 3 - 4 } & 51 & 76 & 24 \\
Sahuayo & 36 & 77.8 & 22.2 \\
Jiquilpan & 11 & 91 & 9 \\
Venustiano Carranza & & \\
\hline
\end{tabular}

Fuente: elaboración propia. * Source: prepared by authors. 
2000) y estos aspectos son los que básicamente observan los usuarios en los flujos que llegan a las viviendas.

Adicionalmente, en el ámbito de las competencias de los OOAPAS, la percepción de los ciudadanos constituye una información primaria para diseñar estudios específicos sobre la calidad del agua, considerando que debe cumplirse el principio de "...agua en cantidad suficiente, saludable y aceptable" enunciado en el Derecho humano al agua (ONU, 2019). Algunos estudios sobre calidad del agua potable en la zona han encontrado que $96 \%$ de los pozos de abastecimiento tienen buena y moderada calidad, mientras que $4 \%$ restante es agua de baja calidad (Velázquez y Pimentel, 2012); sin embargo, estos datos no necesariamente indican el agua llegue con esa calidad a las viviendas puesto que el estado de la red influye también en este indicador.

Así, aunque los sistemas de agua potable de Sahuayo, Jiquilpan y Venustiano Carranza cuentan con una fuente de agua que puede considerarse protegida de contaminación (pozos profundos), entre 9 y $24 \%$ de los usuarios percibe que la calidad del agua es mala o regular. Un aspecto importante que explica también la calidad del agua en Venustiano Carranza es su favorable condición geohidrológica (Velázquez y Pimentel, 2012), que le permite extraer agua de buena calidad; en el caso de Sahuayo y Jiquilpan, esta condición es menos favorable y se tienen problemas de alta salinidad en algunos de los pozos.

Descentralización. El manejo de los sistemas de agua potable en las comunidades rurales, a través de organizaciones autogestivas de usuarios (OAU), se ha observado que es eficiente en un alto porcentaje de casos en la zona (Cervantes et al., 2017); esos pequeños sistemas de abasto se caracterizan por una rotación en los cargos y trabajo no remunerado de usuarios lo que contribuye a bajar costos (Galindo y Palerm, 2012). A partir de estas observaciones, consideramos que la descentralización del servicio desde los OOAPAS hacia las comunidades rurales es un aspecto positivo que incide en la eficiencia de estos organismos.

Los OOAPAS abastecen 93\% de la población municipal en Sahuayo, 70\% en Jiquilpan y 51\% en Venustiano Carranza; el resto de la población municipal (7, 30 y 49\%, respectivamente) es abastecida por una OAU. En los tres municipios existen 87 comunidades rurales (Cuadro 4), de las cuales 44 son
Additionally, in the scope of responsibilities of the OOAPAS, the citizens' perception constitutes primary information to design specific studies about water quality, considering that the principle of "... sufficient, healthy and acceptable water", stated in the human right to water, should be fulfilled (ONU, 2019). Some studies about the quality of drinking water in the zone have found that $96 \%$ of the supply wells have a good and moderate quality, while the remaining $4 \%$ of water is of low quality (Velázquez and Pimentel, 2012); however, these data do not necessarily indicate that water with that quality reaches the households since the state of the network also influences this indicator.

Thus, although the drinking water systems in Sahuayo, Jiquilpan and Venustiano Carranza have a source of water that may be considered protected from pollution (deep wells), between 9 and 24\% of the users perceive that the water quality is bad or regular. An important aspect that also explains water quality in Venustiano Carranza is its favorable geohydrological condition (Velázquez and Pimentel, 2012), which allows extracting water of good quality; in the case of Sahuayo and Jiquilpan, this condition is less favorable and they have problems of high salinity in some of the wells.

Decentralization. The management of drinking water systems in rural communities through selfmanaging users' organizations (organizaciones autogestivas de usuarios, OAU), has been observed to be efficient in a high percentage of cases in the zone (Cervantes et al., 2017); these small supply systems are characterized by a rotation in the positions and unpaid work of users which contributes to lowering costs (Galindo and Palerm, 2012). Based on these observations, we consider that decentralization of the service from OOAPAS toward rural communities is a positive aspect that impacts the efficiency of these organizations.

OOAPAS supply water to $93 \%$ of the municipal population in Sahuayo, 70\% in Jiquilpan and 51\% in Venustiano Carranza; the rest of the municipal population (7, 30 and $49 \%$, respectively) is supplied by an OAU. In the three municipalities there are 87 rural communities (Table 4), of which 44 are supplied by OOAPAS and 43 by OAU; the municipality of Venustiano Carranza has the lowest number of rural communities, but these are the ones with highest percentage $(72 \%)$ supplied by a self-managing users' 
Cuadro 4. Comunidades rurales abastecidas por organismos operadores municipales de agua potable (OOAPAS) y organizaciones autogestivas de usuarios (OAU).

Table 4. Rural communities supplied by municipal drinking water operating organizations (OOAPAS) and self-managing users' organizations (OAU).

\begin{tabular}{lccc}
\hline \multicolumn{1}{c}{ Municipio } & $\begin{array}{c}\text { No. comunidades } \\
\text { rurales }\end{array}$ & $\begin{array}{c}\text { No. de comunidades rurales } \\
\text { abastecidas por un OOAPAS }\end{array}$ & $\begin{array}{c}\text { No. de comunidades rurales } \\
\text { abastecidas por una OAU }\end{array}$ \\
\hline Sahuayo & 29 & 27 & 2 \\
Jiquilpan & 33 & 10 & 23 \\
Venustiano Carranza & 25 & 7 & 18 \\
\hline
\end{tabular}

Fuente: elaboración propia. Source: prepared by authors.

abastecidas por los OOAPAS y 43 por las OAU; el municipio de Venustiano Carranza tiene el menor número de comunidades rurales, pero éstas son el mayor porcentaje $(72 \%)$ abastecido por una organización autogestiva de usuarios (OAU) en relación con Jiquilpan y Sahuayo que tienen el 69.6\% y 6.8\%, respectivamente.

Sobreempleo. En este indicador, el orden que guardan los OOAPAS es: Jiquilpan>Venustiano Carranza>Sahuayo (Cuadro 5). Un índice de 2.0 se considera adecuado, sin sobreempleo, mientras que en América Latina el promedio es de 4.0 (Ferro, 2017). La condición de los OOAPAS de Sahuayo y Venustiano Carranza no presenta, entonces, problemas en este indicador. En Jiquilpan, el mayor valor de sobreempleo se concentra en el número de empleados operadores (por cada 1000 tomas), los cuales se organizan en 7 "cuadrillas" de 3 a 4 personas: agua, bombeos, drenaje, reparto/tandeo, almacén, notificadores y cortes.

Tarifas. La estructura tarifaria para los servicios de agua potable se define de acuerdo con los usos del agua y la ubicación de la vivienda. Para Sahuayo consta de 13 niveles o tipos (Cuadro 6). Así, las viviendas localizadas en fraccionamientos privados pagan la tarifa doméstica residencial, la más eleva$\mathrm{da}$, mientras que en los fraccionamientos populares (fraccionamientos del Instituto del Fondo Nacional organization (OAU) compared to Jiquilpan and Sahuayo which have $69.6 \%$ and $6.8 \%$, respectively.

Overemployment. In this indicator, the order of the OOAPAS is: Jiquilpan >Venustiano Carranza $>$ Sahuayo (Table 5). An index of 2.0 is considered adequate, without overemployment, while in Latin America the average is 4.0 (Ferro, 2017). The condition of the Sahuayo and Venustiano Carranza OOAPAS, therefore, does not present problems in this indicator. In Jiquilpan, the highest value of overemployment is concentrated in the number of operating employees (for every 1000 taps), which are organized into 7 "crews" of 3 to 4 people: water, pumps, drainage, delivery/batches, storage, notifiers, and cuts.

Fees. The fee structure for drinking water services is defined according to water uses and location of the household. For Sahuayo there are 13 levels or types (Table 6). Thus, the households located in private residential developments pay the domestic residential fee, which is the highest, while in the popular residential developments (housing estates from the Institute of the National Housing Fund for Workers - Instituto del Fondo Nacional de la Vivienda para los Trabajadores, INFONAVIT) the middle domestic fee is paid.

The rural communities that are supplied by OOAPAS pay fees of $\$ 70.00$ (La Puntita, La Tunamansa) to $\$ 40.00$ monthly (Rincón de San Andrés).

Cuadro 5. Número de empleados administrativos y operativos en los OOAPAS.

Table 5. Number of administrative and operative employees in the OOAPAS.

\begin{tabular}{lcccc}
\hline $\begin{array}{c}\text { Organismo } \\
\text { operador }\end{array}$ & $\begin{array}{c}\text { No. de Empleados } \\
\text { administrativos }\end{array}$ & $\begin{array}{c}\text { No. de empleados } \\
\text { operadores }\end{array}$ & $\begin{array}{c}\text { Total } \\
\text { empleados }\end{array}$ & $\begin{array}{c}\text { No. empleados } \\
\text { por } 1000 \text { tomas }\end{array}$ \\
\hline Sahuayo & 5 & 43 & 48 & 2.18 \\
Jiquilpan & 12 & 34 & 46 & 3.53 \\
Venustiano Carranza & 10 & 3 & 13 & 2.80 \\
\hline Total & 21 & 77 & 104 & 2.63 \\
\hline Promedio & & & & \\
\hline
\end{tabular}


de la Vivienda para los Trabajadores-INFONAVIT) se paga la tarifa doméstica media.

Las comunidades rurales que son abastecidas por el OOAPAS pagan tarifas de $\$ 70.00$ (La Puntita, La Tunamansa) a $\$ 40.00$ mensuales (Rincón de San Andrés).

Los costos de los servicios adicionales para el suministro de agua potable varían de 80 a 654 pesos (Cuadro 7). Las tarifas son aprobadas por el cabildo, a propuesta del Director del OOAPAS, y autorizadas por la Comisión Estatal de Aguas y Cuencas del estado de Michoacán.

Esta condición legal, donde el congreso local tiene la facultad de autorizar las leyes de ingresos de los municipios, se reconoce como una limitante a la autosuficiencia financiera de los OOAPAS por favorecer la incidencia de criterios políticos en la aprobación de estas leyes (Aguilar, 2011).

El OOAPAS de Jiquilpan cuenta con nueve niveles tarifarios para el pago del servicio de agua potable (Cuadro 8). Existe una tarifa especial para las personas de la tercera edad y para jubilados, que pagan menos de la mitad de la tarifa doméstica. Los servicios de agua para uso público urbano (por ejemplo, parques y jardines, edificios públicos) no se cobran a pesar de que generan gran carga financiera para el organismo operador. La tarifa de agua para las comunidades rurales abastecidas por el OOAPAS es de $\$ 150.00$ mensuales, sin distinción.

El organismo cuenta con importantes ingresos durante los primeros 6 meses del año (enero a junio) por los pagos anticipados que realizan los usuarios en este periodo; en los siguientes 6 meses los ingresos

Cuadro 7. Costos adicionales por diferentes servicios que cobra el OOAPAS de Sahuayo.

Table 7. Additional costs for different services charged by the Sahuayo OOAPAS.

\begin{tabular}{lc}
\hline \multicolumn{1}{c}{ Servicio } & $\begin{array}{c}\text { Costo } \\
(\$)\end{array}$ \\
\hline Costo por concepto de contratos & \\
$\quad$ Normal & $438.00^{*}$ \\
$\quad$ Residencial & 854.00 \\
Conexión de tomas de agua y descargas & 80.00 \\
sanitarias & 90.00 \\
Cambio de Nombre & Sin costo \\
Detección y Reparación de fugas & Sin costo \\
Viajes a través de pipas &
\end{tabular}

*Además del costo del material. * *In addition to the cost of the material.
Cuadro 6. Sistema tarifario del organismo operador en Sahuayo. Table 6. Fee system of the operating organism in Sahuayo.

\begin{tabular}{lcr}
\hline \multicolumn{1}{c}{$\begin{array}{c}\text { Uso del } \\
\text { agua/categoría }\end{array}$} & $\begin{array}{c}\text { Tarifa/mes } \\
(\$)\end{array}$ & \multicolumn{1}{c}{$\begin{array}{c}\text { Tarifa/año } \\
(\$)\end{array}$} \\
\hline Doméstica Baja & 40.00 & 480.00 \\
Doméstica Media & 70.00 & 840.00 \\
Doméstica Normal & 85.00 & 920.00 \\
Doméstica Residencial & 130.00 & 1560.00 \\
Comercial Baja & 209.00 & 2528.00 \\
Comercial Media & 246.00 & 2952.00 \\
Comercial Normal & 478.00 & 5736.00 \\
Comercial Superior & 976.00 & 11712.00 \\
Comercial Especial & 99.00 & 1188.00 \\
Industrial Baja & 186.00 & 2252.00 \\
Industrial Media & 456.00 & 5472.00 \\
Industrial Normal & 812.00 & 9744.00 \\
Industrial Superior & 1160.00 & 13920.00 \\
\hline
\end{tabular}

Fuente: Gobierno Constitucional del Estado de Michoacán de Ocampo, 2014a. Source: Gobierno Constitucional del Estado de Michoacán de Ocampo, $2014 a$.

The costs of additional services for the drinking water supply vary from $\$ 80$ to $\$ 654$ pesos (Table 7 ). The fees are approved by the town council, at the suggestion of the OOAPAS Director and authorized by the State Water and Basin Commission of the state of Michoacán.

This legal condition, where the local congress has the faculty of authorizing the revenue laws of the municipalities, financial self-sufficiency is recognized as a limitation of the OOAPAS to favor the impact of political criteria in the approval of these laws (Aguilar, 2011).

The Jiquilpan OOAPAS has nine fee levels for payment of the drinking water service (Table 8). There is a special fee for elderly and retired people, who pay less than half of the domestic fee. The water services for public urban use (for example, parks and gardens, public buildings) were not charged despite them generating a large financial load to the operating organism. The water fee for rural communities supplied by the OOAPAS is $\$ 150.00$ monthly, without distinction.

The organization has important revenues during the first 6 months of the year (January to June) from advanced payments that users make in this period; in the next 6 months the income is barely enough for payment of expenses in salaries and electricity for pumping. With the revenues from the first six months, installments are made to the debts accumulated in previous periods. 
Cuadro 8. Sistema tarifario del OOAPAS en Jiquilpan.

Table 8. Fee system of the Jiquilpan OOAPAS.

\begin{tabular}{lcrr}
\hline \multicolumn{1}{c}{ Uso } & $\begin{array}{c}\text { Tarifa/mes } \\
(\$)\end{array}$ & $\begin{array}{c}\text { Tarifa/año de enero* } \\
(\$)\end{array}$ & $\begin{array}{c}\text { Tarifa/año de feb-mar } \\
(\$)\end{array}$ \\
\hline Doméstico normal & 150.00 & 1628.00 & 1710.00 \\
Doméstico medio & 112.00 & 1328.00 & 1402.00 \\
Jubilados, Pensionados y 3ra. edad & 70.00 & 832.00 & 878.00 \\
Comercial & 336.00 & 3633.00 & 3835.00 \\
Escolar baja & 607.00 & 6565.00 & 6929.00 \\
Escolar alta & 1112.00 & 12014.00 & 12628.00 \\
Industrial baja & 607.00 & 6565.00 & 6929.00 \\
Industrial media & 1112.00 & 12014.00 & 12682.00 \\
Industrial alta & 1764.00 & 19055.00 & 20114.00 \\
\hline
\end{tabular}

${ }^{1} \mathrm{Si}$ el pago es por el año y lo hacen en enero, tienen un descuento de $10 \% .{ }^{* *}$ En febrero, el pago anual tiene $5 \%$ de descuento. * If payment is per year and they do it in January, there is a discount of $10 \% .{ }^{* *}$ In February, the annual payment has a $5 \%$ discount. *Fuente: Gobierno Constitucional del Estado de Michoacán de Ocampo, 2014b. * *Source: Gobierno Constitucional del Estado de Michoacán de Ocampo, 2014b.

son apenas suficientes para el pago de gastos de salarios y electricidad por concepto de bombeo. Con los ingresos de los primeros seis meses se realizan abonos a las deudas acumuladas en periodos anteriores.

Se calcula que los ingresos por las cuotas recabadas únicamente cubren $60 \%$ de los costos operativos relacionados con el servicio en esas localidades. Otros cobros adicionales se muestran en el Cuadro 9.

La estructura tarifaria en Venustiano Carranza tiene 11 niveles (Cuadro 10) y también cuentan con descuentos a personas jubiladas. Los costos adicionales al servicio (Cuadro 11) varían de 25 a 470 pesos.

El costo medio mensual de la tarifa doméstica en los tres OOAPAS es del orden: Jiquilpan>Vista Hermosa $>$ Sahuayo. Los mayores ingresos por tarifas en Jiquilpan posiblemente se ven neutralizados por los altos costos en sobreeempleo. Considerando el salario mínimo de 88.88 pesos diarios (CONASAMI, 2018), los tres OOAPAS cobran una tarifa menor a 3\% del ingreso por vivienda, porcentaje sugerido como adecuado por la ONU (2019). Este es rubro podría revisarse en los OOAPAS, junto con una adecuada participación de usuarios, con miras a incrementar los ingresos.

Morosidad. La tasa de morosidad en el pago de las cuotas es un problema recurrente en los OOAPAS a nivel nacional (Carabias y Landa, 2005; Salazar y Lutz, 2015). Para los casos estudiados, ésta es del 51, 35 y 20\% (Sahuayo, Jiquilpan y Venustiano Carranza, respectivamente). Para Sahuayo, la mayor morosidad coincide con la mayor intermitencia en el abasto (Cuadro 2) y menor calidad del agua (Cuadro 3); los
It is calculated that the revenues from fees collected only cover $60 \%$ of the operating costs related to service in these localities. Other additional charges are shown in Table 9.

The fee structure in Venustiano Carranza has 11 levels (Table 10) and also has a discount for retired people. The additional costs to the service (Table 11) vary from $\$ 25$ to $\$ 470$ pesos.

The monthly cost of the domestic fee in the three OOAPAS is in the following order: Jiquilpan $>$ Vista Hermosa $>$ Sahuayo. The highest revenues from fees in Jiquilpan are possibly neutralized by the high costs in overemployment. Considering the minimum wage of $\$ 88.88$ pesos daily (CONASAMI, 2018), the three OOAPAS charge a lower fee than $3 \%$ of income per household, percentage suggested as adequate by the

Cuadro 9. Precios por distintos servicios en el OOAPAS de Jiquilpan.

Table 9. Prices for different services of the Jiquilpan OOAPAS.

\begin{tabular}{|c|c|}
\hline Concepto & $\begin{array}{c}\text { Costo } \\
(\$)\end{array}$ \\
\hline Contratos Nuevos & 1850.00 \\
\hline Reconexiones por Baja Temporal & 416.00 \\
\hline Kit de Instalación de toma dom. & 1200.00 \\
\hline Baja Temporal & 400.00 \\
\hline Constancias & 70.00 \\
\hline Cambio de Contrato (Nombre) & 100.00 \\
\hline Costo de $\mathrm{m}^{3}$ de servicio medido & 5.00 \\
\hline
\end{tabular}

Fuente: Gobierno Constitucional del Estado de Michoacán de Ocampo, 2014b. * Source: Gobierno Constitucional del Estado de Michoacán de Ocampo, 2014b. 
Cuadro 10. Estructura tarifaria del OOAPAS en Venustiano Carranza.

Table 10. Fee structure of the Venustiano Carranza OOAPAS.

\begin{tabular}{lcr}
\hline \multicolumn{1}{c}{ Clasificación } & $\begin{array}{c}\text { Tarifa/mes } \\
(\$)\end{array}$ & $\begin{array}{c}\text { Tarifa/año } \\
(\$)\end{array}$ \\
\hline Jubilados & 75.90 & 910.80 \\
Doméstica & 102.85 & 1234.20 \\
Doméstica Mixta & 123.75 & 1485.00 \\
Comercial & 159.50 & 1914.00 \\
Comercial Alta & 273.90 & 3286.80 \\
Industrial Baja & 349.80 & 4197.60 \\
Industrial Alta & 1543.30 & 18519.60 \\
Edificio Público Uso Doméstico & 342.10 & 4105.20 \\
Edificio Público & 330.00 & 3960.00 \\
Edificio Público Maestros & 1651.65 & 19819.80 \\
Planteles Educativos & 718.00 & 8616.00 \\
\hline
\end{tabular}

Fuente: Gobierno Constitucional del Estado de Michoacán de Ocampo, 2014c. * Source: Gobierno Constitucional del Estado de Michoacán de Ocampo, 2014c.

dos últimos aspectos podrían estar desalentando el pago de los usuarios. Las sanciones por morosidad para Jiquilpan y Venustiano Carranza son: a) avisos escritos sobre incumplimiento; b) recargos en las tarifas; y c) cancelación del servicio; en Sahuayo no se reportan cancelaciones del servicio por morosidad.

Autonomía financiera. La relación ingresos/ costos se calculó con base en las tarifas, los salarios de los empleados y el costo por pago de energía eléctrica. No se incluyeron los egresos por mantenimiento de la red por no contar con la información pertinente.

Los salarios de los empleados oscilan entre los 23 000 (directivos) y 5000 (fontaneros) (Cuadro 12). De las tres ciudades, Jiquilpan paga el salario más alto

Cuadro 11. Costo adicional por diferentes servicios del OOAPAS de Venustiano Carranza.

Table 11. Additional cost for different services of the Venustiano Carranza OOAPAS.

\begin{tabular}{lc}
\hline \multicolumn{1}{c}{ Clasificación } & $\begin{array}{c}\text { Costo } \\
(\$)\end{array}$ \\
\hline Cancelación de toma domiciliaria & 190.57 \\
Reconexión de toma domiciliaria & 470.08 \\
Cambio de propietario & 127.05 \\
Cambio de toma domiciliaria & 190.57 \\
Expedición de constancias & 127.05 \\
Aporte perforación de pozo & 190.57 \\
Aporte instalación de toma domiciliaria & 444.67 \\
Recargos & 25.00 \\
\hline
\end{tabular}

Fuente: entrevistas con autoridades de Venustiano Carranza. Source: Interviews with authorities from Venustiano Carranza.
UN (2019). This aspect could be reviewed in the OOAPAS, together with an adequate participation of users, with views to increasing revenues.

Default in payment. The rate of default in payment of the fees is a recurring problem in the OOAPAS at the national level (Carabias and Landa, 2005; Salazar and Lutz, 2015). For the cases studied, it is 51, 35 and 20\% (Sahuayo, Jiquilpan and Venustiano Carranza, respectively). For Sahuayo, the highest default in payment coincides with the highest intermittence in the supply (Table 2) and lower water quality (Table 3); these two aspects could be discouraging payment by the users. The sanctions for default in payment for Jiquilpan and Venustiano Carranza are: a) written notices about the default; b) surcharges in the fees; and c) cancellation of services; in Sahuayo, service cancellations from default in payment are not reported.

Financial autonomy. The revenues/costs rate was calculated based on the fees, the salaries of the employees and the cost for payment of electric energy. This did not include the expenditure over maintenance of the network because the pertinent information was not available.

The salaries of employees range between 23000 (directives) and 5000 (plumbers) (Table 12). Of the three cities, Jiquilpan pays the highest salary to the OOAPAS directive, while the lowest corresponds to Venustiano Carranza.

The total expenditure by concept of salaries (Table 13) follows the order: Sahuayo > Jiquilpan > Venustiano Carranza; the monthly expenditure of 
Cuadro 12. Salarios de algunos puestos en los organismos operadores.

Table 12. Salaries of some positions in the operating organizations.

\begin{tabular}{lcc}
\hline Organismo operador & $\begin{array}{c}\text { Salario mensual }(\$)^{*} \\
\text { Director del OOAPAS }\end{array}$ & $\begin{array}{c}\text { Sueldo mensual }(\$) \\
\text { Fontanero }\end{array}$ \\
\hline Sahuayo & 20000.00 & 5103.00 \\
Jiquilpan & 23175.00 & 6564.00 \\
Venustiano Carranza & 15375.00 & 6495.00 \\
\hline
\end{tabular}

Fuente: elaboración propia en base en entrevistas a empleados de organismos operadores y Presupuesto de Ingresos y Egresos del Departamento de Agua Potable de Sahuayo, 2013. * Source: prepared by authors based in interviews with employees of operating agencies and the Income and Expenditure Budget of the Drinking Water Department in Sahuayo, 2013.

*Pesos * *Pesos

al directivo del OOAPAS, en tanto que el más bajo corresponde a Venustiano Carranza.

El gasto total por concepto de salarios (Cuadro 13) sigue el orden: Sahuayo $>$ Jiquilpan $>$ Venustiano Carranza; el gasto mensual de salarios por pozo, sin embargo, es mayor en Jiquilpan que en Venustiano Carranza y Sahuayo. Esto evidencia nuevamente un exceso de personal administrativo en Jiquilpan.

La relación ingresos/costos es deficitaria para los OOAPAS de Sahuayo y Jiquilpan (Cuadro 14); en estos organismos el gasto en energía eléctrica es 2.5 y 2.7 veces mayor que Venustiano Carranza. A decir de las autoridades, este alto costo energético se asocia principalmente al elevado número de fugas en la red (pérdidas por conducción), a la complejidad de la red y a una disminución en el aforo de los pozos.

El déficit financiero en Sahuayo y Jiquilpan es cubierto por el Ayuntamiento, situación que vulnera su autonomía. La baja recaudación y dependencia de los Ayuntamientos son condiciones que han sido señaladas como problema común en distintos países de América Latina en los servicios de agua potable (Jouravlev, 2003; Ferro, 2017).

En Sahuayo y Jiquilpan, la insostenibilidad financiera se agudiza por problemas como: compleja distribución del agua, derivada de la topografía accidentada, salaries per well, however, it is higher in Jiquilpan than in Venustiano Carranza and Sahuayo. This evidences again an excess of administrative personnel in Jiquilpan.

The revenues/costs rate has a negative balance for the Sahuayo and Jiquilpan OOAPAS (Table 14); in these organizations the expenditure in electric energy is 2.5 and 2.7 times higher than in Venustiano Carranza. According to the authorities, this high energetic cost is associated primarily to the high number of leaks in the network (losses from conduction), to the complexity of the network, and to a decrease in the capacity of the wells.

The financial deficit in Sahuayo and Jiquilpan is covered by the Local Government, situation that infringes on their autonomy. The low collection and dependency of Local Governments are conditions that have been pointed out as a common problem in different countries of Latin America in drinking water services (Jouravlev, 2003; Ferro, 2017).

InSahuayo and Jiquilpan, financial unsustainability is aggravated by problems such as: complex water distribution, derived from uneven topography, rising urban growth, timeworn infrastructure, and centralized decision making. However, the fact that 99 and $97 \%$ of the population enjoy drinking water

Cuadro 13. Número de empleados administrativos y operativos y costos salariales de los mismos.

Table 13. Number of administrative and operative employees, and salary costs of employees.

\begin{tabular}{lccc}
\hline $\begin{array}{c}\text { Organismo } \\
\text { operador }\end{array}$ & $\begin{array}{c}\text { Número total } \\
\text { de empleados }\end{array}$ & $\begin{array}{c}\text { Gasto mensual } \\
\text { empleados }(\$)\end{array}$ & $\begin{array}{c}\text { Gasto mensual por pozo } \\
(\text { salarios })\end{array}$ \\
\hline Sahuayo & 48 & 301064 & 20070 \\
Jiquilpan & 46 & 273439 & 34179 \\
Venustiano Carranza & 13 & 63544 & 21181 \\
\hline
\end{tabular}

Fuente: entrevistas con autoridades del agua. \$ Source: Interviews with water authorities. 
Cuadro 14. Ingresos y egresos anuales de los OOAPAS de Sahuayo, Jiquilpan y Venustiano Carranza, Michoacán. Table 14. Annual revenues and expenditures of the Sahuayo, Jiquilpan and Venustiano Carranza OOAPAS, Michoacán.

\begin{tabular}{lccccc}
\hline \multicolumn{1}{c}{ OOAPAS } & $\begin{array}{c}\text { Ingresos } \\
(\$)\end{array}$ & $\begin{array}{c}\text { Sueldos } \\
(\$)\end{array}$ & $\begin{array}{c}\text { Energía eléctrica } \\
(\$)\end{array}$ & $\begin{array}{c}\text { Egresos anuales } \\
(\$)\end{array}$ & Relación I/E** $^{*}$ \\
\hline Sahuayo & 9245571 & 3612768 & 11226405 & 14839173 & 0.623 \\
Jiquilpan & 5815252 & 3281268 & 6637116 & 9918384 & 0.586 \\
Venustiano Carranza & 2328145 & 762528 & 899716 & 1662244 & 1.40 \\
\hline
\end{tabular}

*Incluye sueldos + costo de energía eléctrica. ${ }^{* *}$ Relación ingresos/egresos. * Includes salaries + cost of electric energy. ${ }^{* *}$ Revenues/expenditures rate.

Fuente: elaboración propia con base en entrevistas, informes oficiales y presupuestos anuales. Source: prepared by authors based on interviews, official reports, and annual budgets.

crecimiento urbano en ascenso, infraestructura desgastada y toma de decisiones centralizadas. Sin embargo, se resalta el hecho de que 99 y $97 \%$ de la población cuenta con el servicio de agua potable, mayor que el promedio nacional de 94.5\% (INEGI, 2017), y de que se cuente con mecanismos compensatorios para usuarios con escasos recursos (pensionados, jubilados, tercera edad).

\section{CONCLUSIONES}

El OOAPAS de Venustiano Carranza mostró mayor eficiencia y eficacia para el abasto de agua potable (menor intermitencia y mayor número de horas/ día del servicio, mejor calidad del agua (percepción), menor morosidad y mayor relación ingresos/egresos), mientras la menor se observó en el OOAPAS de Jiquilpan. El menor tamaño del OOAPAS de Venustiano Carranza, mayor descentralización hacia las comunidades rurales (manejo autogestivo de los sistemas) y los menores costos por pozo podrían estar favoreciendo su autonomía financiera. Jiquilpan y Sahuayo tienen déficit financiero que cubren con fondos municipales; esta condición los hace vulnerables a presiones políticas por parte de las autoridades municipales en turno. Los OOAPAS no cuentan con mecanismos para garantizar la participación directa de los usuarios en la gestión de los sistemas y no tienen sistemas de saneamiento de aguas residuales. En los tres municipios, la cobertura de agua potable es mayor a la media nacional y cuentan con mecanismos compensatorios en el pago de tarifas para usuarios con escasos recursos.

\section{Agradecimientos}

Los autores agradecen a la Dra. Jacinta Palerm Viqueira (Colegio de Postgraduados) las sugerencias services stands out, which is higher than the national average of $94.5 \%$ (INEGI, 2017), as well as there being compensatory mechanisms for users with scarce resources (retirees, elderly people).

\section{CONCLUSIONS}

The Venustiano Carranza OOAPAS showed higher efficiency and effectiveness for the supply of drinking water (lower intermittence and higher number of hours/day of the service, better water quality (perception), lower default in payment, and higher revenues/expenditures rate), while the lowest was observed in the Jiquilpan OOAPAS. The smaller size of the Venustiano Carranza OOAPAS, greater decentralization toward rural communities (selfmanagement of the systems), and lower costs per well could be favoring its financial autonomy. Jiquilpan and Sahuayo have financial deficit that they cover with municipal funds; this condition makes them vulnerable to political pressures from the municipal authorities in turn. The OOAPAS do not have mechanisms to guarantee the direct participation of users in the management of the systems and do not have sanitation systems for residual water. In the three municipalities, the coverage of drinking water is higher than the national mean and they have compensatory mechanisms in the payment of fees for users with scarce resources.

- End of the English version-

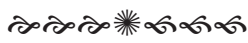

hechas al trabajo y al Instituto Politécnico Nacional y Colegio de Postgraduados por el financiamiento. 


\section{LITERATURA CITADA}

Aguilar, Enrique. 2011. Gestión comunitaria de los servicios de agua y saneamiento: su posible aplicación en México. México, Ed. MDG Achievement Fund, Naciones Unidas.

Barkin, David (coord) 2006. La gestión del agua urbana en México. Retos, debates y bienestar. Guadalajara, Jal., México. Ed. Universidad de Guadalajara, 2006

Barkin, David. 2011. La ingobernabilidad en la gestión del agua urbana en México. In: Úrsula Oswald (ed). Retos de la investigación del agua en México. México, UNAM-CRIMCONACYT, pp: 539-551.

Carabias, Julia, y R. Landa. 2005. Agua, medio ambiente y sociedad. Hacia la gestión integral de los recursos hídricos en México, México, Colegio de México.

Castro, José Esteban. 2007. La privatización de los servicios de agua y saneamiento en América Latina. Nueva Sociedad. Vol.27, Núm. 93.

Cervantes Martínez, América Alejandra, Martha Alicia Velázquez Machuca, y José Luis Pimentel Equihua. 2017. Gobierno y manejo social del agua potable en la Ciénega de Chapala, Michoacán. Tecnología y Ciencias del Agua. Vol. VIII, Núm. 1.

CONAGUA (Comisión Nacional del Agua). 2014. Manual de agua potable y alcantarillado. Estructuras tarifarias. Recuperado 04/02/2019 de http://aneas.com.mx/wp-content/ uploads/2016/04/SGAPDS-1-15-Libro54.pdf.

Congreso de Michoacán de Ocampo. 2004. Ley de Agua Potable y Alcantarillado del Estado de Michoacán. Constitución Política de Los Estados Unidos Mexicanos (s/f). Recuperado de http://info4.juridicas.unam.mx/ijure/fed/9/5.htm.

Contreras Zepeda, Hugo. 2006. ¿Tienen los organismos de agua en México los incentivos para lograr una gestión eficiente de los servicios de agua potable, alcantarillado y saneamiento? In: Barkin, David. (coord). La Gestión del Agua Urbana en México. Retos, debates y bienestar. Guadalajara, Jal., México, Universidad de Guadalajara. pp: 75-101.

CONASAMI (Comisión Nacional de los Salarios Mínimos). 2018. Evolución del salario mínimo real. Recuperado 04/02/2019 de https://www.gob.mx/cms/uploads/attachment/ file/394931/2018AGO-SalarioMinimoRealNPCGral.pdf.

Cunha Marques, Rui, Nuno Ferreira da Cruz, and Joao Pires. 2015. Measuring the sustainability of urban water services. Environmental Science \& Policy. Vol. 54.

Dong, Xin, Du Xinming, Li Ke, Zeng Siyu, and Brian P. 2018. Bledsoe. Benchmarking sustainability of urban water infrastructure systems in China. Journal of Cleaner Production. Vol. 170.

Ferro, Gustavo. 2017. América Latina y el Caribe hacia los Objetivos de Desarrollo Sostenible en agua y saneamiento. Reformas recientes de las políticas sectoriales. CEPAL.

Galindo, Emmanuel y Jacinta Palerm. 2012. Toma de decisiones y situación financiera en pequeños sistemas de agua potable: dos casos de estudio en El Cardonal, Hidalgo, México. Región y Sociedad. Vol. 54.

Gobierno Constitucional del Estado de Michoacán de Ocampo. 2014a. Tarifas de Agua Potable para el Ejercicio Fiscal 2014. H. Ayuntamiento Constitucional de Sahuayo, Michoacán. Periódico Oficial, Tomo CLVIII, 76.
Gobierno Constitucional del Estado de Michoacán de Ocampo. 2014b. Tarifas de Agua Potable para el ejercicio fiscal 2014. H. Ayuntamiento Constitucional de Jiquilpan, Michoacán. Periódico Oficial, Tomo CLVIII, 55.

Gobierno Constitucional del Estado de Michoacán de Ocampo. 2014c. Presupuesto de Ingresos y Egresos para el Ejercicio Fiscal 2014. H. Ayuntamiento Constitucional de Venustiano Carranza, Michoacán. Periódico Oficial, Tomo CLIX, 14.

Halkijevic, Ivan, Zivko Vukovic, and Vouk Drazen. 2017. Indicators and a Neuro-Fuzzy Based Model for the Evaluation of Water Supply Sustainability. Water Resources Management. Vol. 31.

INAFED (Instituto Nacional para el Federalismo y el Desarrollo Municipal). 2014. Enciclopedia de los Municipios y Delegaciones de México. Recuperado de http://siglo.inafed.gob. $\mathrm{mx} /$ enciclopedia/EMM16michoacan/municipios/16045a. html.

INEGI (Instituto Nacional de Estadística y Geografía). 2010. Censo Nacional de Población y Vivienda 2010. Recuperado 02/05/2017 de http://www.inegi.org.mx/sistemas/consulta_resultados/iter2010.aspx?c=27329\&s=est.

INEGI (Instituto Nacional de Estadística y Geografía). 2015. México en cifras. Recuperado 01/02/2019 de https://www. inegi.org. $\mathrm{mx} / \mathrm{app} /$ areasgeograficas/?ag=16\#.

INEGI (Instituto Nacional de Estadística y Geografía). 2017. Indicadores Nacionales. Recuperado 02/02/2019 de https:// www.inegi.org.mx/app/buscador/default.html?q=cobertura+ agua+potable\#tabMCcollapse-Indicadores.

Jouravlev, Andrei. 2003. Los municipios y la gestión de recursos hídricos. Recuperado http://repositorio.cepal.org/bitstream/ handle/11362/6429/1/S0310753_es.pdf.

Martín, Alejandro, Víctor Javier Bourguett, Flor Cruz Gutiérrez, Miguel Ángel Mejía González, Juan Maldonado Silvestre, Gustavo Armando Ortíz Rendón, Petronilo Cortés Mejía, Arturo González Herrera, Martín Piña Soberanis, María de Lourdes Rivera Huerta, Leticia Montellano Palacios, Víctor Hugo Alcocer Yamanaka, Carlos Eduardo Mariano Romero, y Velitchko Georguiev Tzatchkov. 2011. Diagnóstico de un organismo operador. Descripción de la metodología. In: Úrsula Oswald (ed). Retos de la investigación del agua en México. México, UNAM-CRIM-CONACYT. pp: 593-604.

ONU (Organización de las Naciones Unidas). 2019. Observación General No. 15. El derecho al agua. Comité de Naciones Unidas de Derechos Económicos, Sociales y Culturales. Recuperado 04/02/2019 de http://www.un.org/spanish/ waterforlifedecade/human_right_to_water.shtml.

Ostrom, Elinor. 1990. Governing the Commons. The Evolution of Institutions for Collective Action. Cambridge, UK, Cambridge University Press.

Palerm, Jacinta, Tomás Martínez, y Francisco Escobedo. 2000. Modelo de investigación: organización social de sistemas de riego en México. In: J. Palerm-Viqueira \& T. MartínezSaldaña (ed). Antología Sobre Pequeño Riego Volumen II. Organizaciones Autogestivas. México, Plaza \& Valdés Editores. pp: 31-60.

Salazar Adams, Alejandro, y América N. 2015. Lutz Ley. Factores asociados al desempeño en organismos operadores de agua potable en México. Región y sociedad. Vol. XXII, Núm. 62.

Sandoval-Moreno, Adriana. 2011. Entre el manejo comunitario y gubernamental del agua en la Ciénega de Chapala, Mi- 
choacán, México. Agricultura, Sociedad y Desarrollo, vol. 8, núm. 3, septiembre-diciembre.

SSA (Secretaría de Salud). 2000. Modificación a la Norma Oficial Mexicana NOM-127-SSA1-1994. Salud Ambiental. Agua para uso y consumo humano. Límites permisibles de calidad y tratamientos a que debe someterse el agua para su potabilización. DOF (Diario Oficial de la Federación 22/11/2000).

Pimentel, José Luis, Martha Alicia Velázquez, y Jacinta Palerm. 2012. Capacidades locales y de gestión social para el abasto de agua doméstica en comunidades rurales del valle de $\mathrm{Za}$ mora, Michoacán, México. Agricultura, Sociedad y Desarrollo. Vol. 9, Núm. 2.

Velázquez, Martha, y José Luis Pimentel. 2012. Calidad del agua potable en la Ciénaga de Chapala, Michoacán. Tecnología y Ciencias del Agua, Vol. III. Número especial TYCA-RETAC.

Yonca Aydin, Nazly, Larry Mays, and Theo Schmitt. 2014. Sustainability assessment of urban water distribution systems. Water Resources Management. Vol. 28. 